\title{
Trauma, memória e latência em Diário da queda, de Michel Laub
}

\author{
Rejane Cristina Rocha*
}

\begin{abstract}
Del pasado no se prescinde por el ejercicio de la decisión ni de la inteligencia; tampoco se lo convoca simplemente por un acto de la voluntad. El regreso del pasado no es siempre un momento liberador del recuerdo, sino un advenimiento, una captura del presente.
\end{abstract}

Beatriz Sarlo

\section{A recepção crítica de Diário da queda}

Publicado em 2011, Diário da queda é o quinto romance de Michel Laub, cuja estreia na literatura ocorreu em 1998, com o volume de contos Não depois do que aconteceu. Diário da queda foi anunciado como o primeiro de uma trilogia de romances composta por $A$ maçã envenenada, publicado em 2013, e $O$ tribunal de quintafeira, publicado em 2016 - trilogia esta que marcaria também o encerramento de um ciclo em sua carreira de escritor, uma vez que ele não mais se dedicaria a esse gênero romanesco identificado, por ele mesmo, como "romance de formação".

Desde seu lançamento, o romance Diário da queda tem motivado apreciações críticas de diferentes estofos, mas não é incomum que, de resenhas a artigos de maior fôlego, tais apreciações mobilizem conceitos como os de memória, autobiografia e autoficção, no intuito de investigar - às vezes, no caso das resenhas mais ligeiras, identificar - os traços que, no interior do ambiente romanesco, pudessem ser aproximados aos fatos vividos pelo escritor Michel Laub. O interesse nessa possível identificação entre os elementos episódicos que compõem a trama romanesca e fatos "vividos" por Laub e seus familiares motiva também um sem número de questões a respeito de ser Diário da queda um romance autobiográfico. Se esse interesse pode ser motivado, como afirma um entrevistador, "por culpa

"Doutora em estudos literários e professora da Universidade Federal de São Carlos (UFSCar), São Carlos, SP, Brasil. E-mail: rjncris@gmail.com

${ }^{1}$ A declaração foi dada pelo escritor em novembro de 2013, em evento realizado na Biblioteca Pública do Paraná (PARANÁ, 2013). 
do próprio autor", que interpõe no enredo ficcional aspectos que poderia ter "vivido", não é ocioso questionar por que com Maçã envenenada a recepção foi outra, sendo o segundo romance parte da trilogia anunciada por Laub. A resposta, parcial neste momento, pode estar no fato de que os episódios narrados no primeiro romance terem como sustentação histórica a Shoah e suas terríveis consequências para os judeus do mundo todo, ou seja, um apelo e tanto, que resgataria o ficcional desse limbo da mentira ao qual a contemporaneidade e sua "vontade de verdade" parecem tê-lo lançado.

Se muitas das apreciações mais ligeiras leem o texto de Laub na chave do autobiográfico, a despeito de o escritor recusar tal designação, ${ }^{2}$ outras preferem mobilizar o conceito de autoficção, tornando um pouco mais complexa a discussão. É o caso, por exemplo, de Luciana Hidalgo (2013, p. 219) que, embora admita a nebulosidade de um conceito "flutuante entre a prática criativa dos autores e o olhar científico dos teóricos, entre a leitura referencial e a leitura ficcional, o eu real e o eu fictício", não se furta a identificar o romance de Laub, que aqui discutimos, como uma "autoficção anominal ou nominalmente indeterminada" (HIDALGO, 2013, p. 224), a partir dos preceitos de Serge Doubrouvski, o criador do termo. Esse tipo de autoficção seria aquela em que não necessariamente o nome do personagem se identificaria ao nome do autor, mas que guardaria traços referenciais, pistas que possibilitariam a identificação personagem-autor em outros níveis.

Como se sabe, ${ }^{3}$ o conceito, nascido no ambiente francófono, ainda hoje gera discussões e polêmicas em seu país de origem; discussões e polêmicas que se aprofundaram no momento em que o conceito ganhou mundo e, na opinião de Diana Klinger (2008), perdeu sua especificidade e operacionalidade teórica, ao ser empregado para apreciar textos e autores tão diferentes quanto Infância, de Graciliano Ramos, de um lado, e Las aventuras del Sr. Maiz, de Washington Cucurto, de outro.

Klinger (2008) não recusa a pertinência do conceito de autoficção, mas problematiza seu emprego para analisar obras que não sejam contemporâneas, isso porque, segundo a ensaísta, a especificidade do texto autoficcional se encontra na articulação de dois aspectos contemporâneos: por um lado, a voracidade midiática, que demanda cada vez mais que autores - e artistas em geral - ofereçam nacos de sua personalidade e privacidade no altar das feiras, entrevistas, festivais e concursos; e, por outro, a compreensão do que seja essa personalidade e privacidade na era do pós-pós-estruturalismo, que prognosticou a crise do sujeito. Em suas palavras:

Parto da hipótese de que a autoficção se inscreve no coração do paradoxo deste final de século XX: entre um desejo narcisista de falar de si e o reconhecimento da impossibilidade de exprimir uma "verdade" na escrita. Assim, a autoficção se aproxima do conceito de performance, que,

\footnotetext{
${ }^{2}$ A esse respeito, ver a entrevista concedida pelo escritor para a Folha de S. Paulo (BrendLer, 2011) e para o suplemento "Rascunho" (Pereira, 2011).

${ }^{3}$ Para a discussão do conceito de autoficção, consulte-se Hidalgo (2013) e Klinger (2012, 2008).
} 
como espero mostrar, também implica uma desnaturalização do sujeito (KLINGER, 2008, p. 18-19).

Para além da reflexão concernente ao âmbito literário, mas ainda refletindo a respeito do fenômeno que, com Nietzsche, ela identifica como sendo uma "vontade de verdade", Jeanne Marie Gagnebin (2006) questiona-se a respeito das motivações relacionadas à busca pelo estabelecimento da "verdade", que a autora julga deletéria para a ciência histórica, e que tem contaminado também as artes - o impulso histórico, autobiográfico, realista da literatura e, sobretudo, da leitura crítica que dela se faz, não seria também mais um sintoma dessa "vontade de verdade"? Segundo a autora, a abordagem positivista que parte da ciência histórica insiste em praticar faria submergir um aspecto essencial da história que diz respeito ao fato de que "Nós articulamos o passado, [...] nós não o descrevemos, como se pode tentar descrever um objeto físico, mesmo com todas as dificuldades que essa tentativa levanta, das classificações de Lineu aos Métodos de Francis Ponge" (GAGNEBin, 2006, p. 40).

E articular o passado significa manejar a memória, o que torna imperativo lidar com a subjetividade e a instabilidade, abandonando a "vontade de verdade" para encontrar a verdade não nos fatos objetivamente descritos do passado, mas nos rastros que tais fatos imprimiram nas subjetividades:

Esse conceito de rastro nos conduz à problemática, brevemente evocada, da memória. [...] Seja sobre tabletes de cera ou sobre uma "lousa mágica"essas metáforas privilegiadas da alma -, o rastro inscreve a lembrança de uma presença que não existe mais e que sempre corre o risco de se apagar definitivamente. Sua fragilidade essencial e intrínseca contraria assim o desejo de plenitude, de presença e de substancialidade que caracteriza a metafísica clássica. [...] Por que a reflexão sobre a memória utiliza tão frequentemente a imagem - o conceito - de rastro? Porque a memória vive essa tensão entre a presença e a ausência, presença do presente que se lembra do passado desaparecido, mas também presença do passado desaparecido que faz sua irrupção em um presente evanescente (GAGNEBIN, 2006, p. 44).

\section{Memória e escrita}

Do que foi posto até este momento, assinalamos que a discussão a respeito dos limites pouco discerníveis entre realidade e ficção que pontua a recepção crítica de Diário da queda não é, propriamente, o que anima este artigo. Seria interessante sublinhar, outrossim, que, a nosso ver, o conceito que fundamenta essa discussão - que identifica no romance de Laub traços autobiográficos ou uma performance autoficcional - e é anterior a ela, é o de memória. Memória enquanto procedimento narrativo, constituído por uma notável plasticidade do tempo ficcional que, 
por sua vez, mobiliza esferas de experiência distintas: histórica e subjetiva. Em outras palavras, partimos do pressuposto de que a realização ficcional do romance Diário da queda se organiza a partir da elaboração ficcional, narrativa, do tempo histórico imbricado ao tempo subjetivo e que o romance pode ser compreendido na chave metafórica que identifica a memória à escrita e ambas ao rastro. Memória e escrita garantem a presença de signos ausentes, na mesma medida em que o rastro exige um trabalho de decifração que está para além de sua própria existência.

É nesse sentido que o conceito de rastro merece atenção desde a sua significação metafórica amplamente problematizada pela filosofia. Lembra-nos Jeanne Marie Gagnebin (2006, p. 112) que:

Rastro [...] é fruto do acaso, da negligência, às vezes da violência [...]. Como quem deixa rastros não o faz com intenção de transmissão ou de significação, o decifrar dos rastros também é marcado por essa nãointencionalidade. O detetive, o arqueólogo e o psicanalista, esses primos menos distantes do que podem parecer à primeira vista, devem decifrar não só o rastro na sua singularidade concreta, mas também tentar adivinhar o processo, muitas vezes violento, de sua produção involuntária. Rigorosamente falando, rastros não são criados - como são outros signos culturais e linguísticos -, mas sim deixados ou esquecidos.

O narrador-personagem - detetive, arqueólogo e psicanalista - decifra esses rastros, essas memórias de segundo grau, ${ }^{4}$ não para determinar a verdade por trás delas, mas para compreender o processo da sua constituição e a forma como esse mesmo processo se articula com sua identidade e com suas próprias memórias e possibilidades para o futuro. E é nesse aspecto que ele se distancia do detetive, do arqueólogo e do psicanalista, que não veem sua constituição identitária implicada nesse processo, e se aproxima da testemunha, no sentido alargado que Gagnebin confere ao termo:

Testemunha também seria aquele que não vai embora, que consegue ouvir a narração insuportável do outro e que aceita que suas palavras levem adiante, como num revezamento, a história do outro: não por culpabilidade ou por compaixão, mas porque somente a transmissão simbólica, assumida apesar e por causa do sofrimento indizível, somente essa retomada reflexiva do passado pode nos ajudar a não repeti-lo infinitamente, mas a ousar esboçar uma outra história, a inventar o presente.

Sublinhe-se, ainda, que a perspectiva da qual partimos é a de que Diário da queda, a despeito do que apontam alguns resenhistas, com anuência ou não do

\footnotetext{
${ }^{4}$ Remeto, aqui, à interessante reflexão promovida por Beatriz Sarlo $(2005$, p. 128) a respeito do conceito de "pós-memória", cunhado por Marianne Hirsch. No âmbito dessa discussão, afirma Sarlo: "esa memoria [resultante da experiência direta] puede convertirse en un discurso producido en segundo grado, com fuentes secundarias que no provienen de la experiencia de quien ejerce esa memoria, pero sí de la escucha de la voz (o la visón de las imágenes) de quienes están implicados en ella".
} 
autor, é um texto ficcional que forja a memória e o testemunho - ainda que em tal elaboração possa manejar memória e testemunho "reais". Na realidade, trata-se de texto ficcional que elabora suas instâncias narrativas para fazer deslizar as fronteiras entre o histórico, o subjetivo e individual, o ficcional. Explora, para isso, a narrativa em primeira pessoa, em que um personagem narra fatos relativos a sua história pessoal, familiar e, além disso, o que contribui para esse deslizamento que mencionamos, insere tais fatos no interior de uma cronologia histórica de eventos traumáticos e de grande repercussão, articulando cuidadosamente o histórico ao subjetivo.

Em sua abordagem estrutural da narrativa, Gerard Genette (1995) nos oferece elementos narratológicos para compreender como se dá a organização do discurso memorialístico construído em primeira pessoa. A articulação entre a instância narrativa e a posição que ela assume em relação à história que narra é um dos fundamentos de seu reconhecido ensaio de método que toma o romance de Proust, Em busca do tempo perdido, como ponto de partida de reflexão.

Interessa-nos retomar a proposição metodológica de Genette (1995) na medida em que ela nos oferece elementos consistentes para compreender de que forma $o$ discurso narrativo do romance em questão é forjado de modo a compor-se como uma espiral de temporalidades distintas que possuem como eixo o tempo da possibilidade, o futuro de um personagem que é também narrador. Pode-se afirmar que o personagem narrador, instância que em si faz coincidir o "eu narrante" e o "eu narrado", articula às suas memórias, outras, de segundo grau - a do seu pai e a do seu avô -, além de uma "memória histórica", já que suas memórias familiares se entrelaçam com um evento catastrófico de dimensão coletiva, que é a Shoah. Com relação às suas memórias, três eventos principais dominam a cena narrativa: a queda de um amigo não judeu durante uma festa de aniversário, a descoberta da doença do seu pai e a leitura dos cadernos do avô. Sabe-se que, no presente da narrativa, o personagem narrador tem 40 anos e que descobriu, há dois anos, que seu pai estava com os primeiros sintomas do Alzheimer. Embora tal informação não esteja explicitada, a leitura de cadernos que o avô, sobrevivente de Auschwitz, escrevera antes de se suicidar ocorreu antes dessa descoberta e ambos os fatos, a descoberta do Alzheimer e a leitura dos cadernos, é o que motiva a revisão memorialística a respeito dos fatos da sua infância - a queda do amigo de escola ocorrera quando ele tinha 13 anos -, a respeito dos quais nunca falou com ninguém.

As memórias a respeito do evento acontecido na infância - e de tudo o que se sucedeu a partir disso - são narradas a partir de uma estratégia iterativa que é dominante no romance: o mesmo evento e suas consequências são narrados repetidamente e aparecem ora como causa ora como consequência de vários outros eventos, até o presente da narrativa. Tal estratégia é possível graças ao fato de que a instância narrativa, no caso da narração em primeira pessoa, é passível de um desdobramento: o narrador tem condições de olhar para seu passado distanciando-se dele e a partir de uma perspectiva que é outra e só é possível graças ao fato de que 
existe um lapso temporal (de cerca de 30 anos) entre o que aconteceu na infância e o momento em que ele narra o que aconteceu naquela época. Nesse sentido, o evento da infância é interpretado pelo narrador-personagem como um momento fundador, a partir do qual ele revisará sua vida, sua relação com seu pai, sua relação com a memória do avô, sua relação com a Shoah. Não é por outro motivo que a narrativa na primeira parte do romance obedece a um ritmo arrastado, em que há menos eventos e mais reflexões a respeito de alguns poucos eventos.

Em comparação com a primeira, a segunda metade da narrativa explicita uma maior proximidade temporal entre os eventos narrados e o momento de sua narração, mas não só isso: não se trata apenas de sabermos que, agora, os acontecimentos narrados aconteceram há menos tempo, mas, sobretudo, de refletir sobre os motivos e consequências de a narrativa, nessa altura do romance, adquirir outra velocidade. É clássica a leitura que Lafetá (2004) faz de São Bernardo, mostrando como, estruturalmente, com estratégias relacionadas ao emprego do sumário, por um lado, para falar do passado e da juventude de Paulo Honório e, por outro, ao emprego do monólogo e do fluxo de consciência, para comunicar eventos próximos do tempo da narração, Graciliano pôde mostrar o percurso de vida de seu personagem, arrebatado, a certa altura, por um amor que ele não compreendia e não tinha capacidade de experimentar. O que ocorre em Diário da queda é, também, a exploração da velocidade narrativa, mas de um modo diferente e, evidentemente, com outros significados. A partir da segunda metade do romance, o narrador aproxima-se do personagem e os eventos mais próximos são narrados de forma bastante concisa e objetiva. Em poucos parágrafos dá-se a conhecer, ao leitor, que o narrador-personagem foi casado três vezes, separou-se duas, tornou-se alcoólatra, desenvolveu uma carreira. Tal configuração narrativa, que aposta na iteração para comunicar alguns eventos, poucos, relativos ao passado - do próprio narrador-personagem ou do seu pai ou do seu avô - e no sumário para narrar o momento presente assume um significado peculiar que discutiremos na terceira seção deste ensaio.

Dito isso, detalhemos a organização estrutural do romance a partir da(s) história(s) que narra. Relacionam-se, na trama, temporalidades relativas a pelo menos três experiências de vida que, por sua vez, afetam-se. Numa ponta, o tempo do personagem avô do narrador autodiegético, um homem judeu, sobrevivente de Auschwitz, marcado pelos traumas da Shoah, inclusive o trauma de ter sobrevivido. Esse personagem, ao ser libertado de Auschwitz, muda-se para o Brasil, onde constitui família e recusa a narrativa do trauma, construindo, em seu lugar, um enredo irônico-cínico sobre a sua vida pós-libertação:

Aparentemente meu avô queria escrever uma espécie de enciclopédia, um amontoado de verbetes sem relação entre si, termos seguidos por textos curtos ou longos, sempre com uma característica peculiar. O verbete leite, por exemplo, fala de um alimento líquido e de textura cremosa que além de conter cálcio e outras substâncias essenciais ao organismo tem a vantagem 
de ser muito pouco suscetível ao desenvolvimento de bactérias (LAUB, 2011, cap. "Algumas coisas que sei sobre o meu pai", subcap. 2). ${ }^{5}$

Tal enredo, documentado em cadernos em que o avô narra, às avessas, sua experiência de vida desde a chegada ao Brasil, passando pelo seu casamento e o nascimento do filho, é o documento que permite ao narrador autodiegético ter acesso a esse avô que ele não conheceu, morto quando seu pai tinha apenas 14 anos, e sobre o qual sua avó apenas mencionara coisas pouco importantes. Seu avô, uma espécie de Pangloss a quem se suprimira a ingenuidade, é essas linhas escritas, mas não só, uma vez que tais linhas são apreendidas e processadas por um sujeito cuja história de vida lhe permite uma determinada leitura dessas linhas. E é a essa leitura que o leitor tem acesso.

Entre o avô e o próprio narrador há o pai. Aquele cujo próprio pai se suicidara depois de ter passado anos e anos trancado no escritório, debruçado sobre papéis que, só depois de sua morte, seriam conhecidos e que revelavam não quem era esse pai, como tinha sido sua vida, de que forma encarava o fato de ter tido um filho depois de ter vivido os horrores da Shoah, mas um efabulador que registrava o que deveria ter sido - ou o que ele gostaria que tivesse sido - e não foi. O esforço de dar sentido a esse espaço da vacuidade ocupado por esse pai suicida é, em grande medida, o que caracteriza o pai do narrador: a presença constante que ampara e também cerceia, que não só conta como também explica. O narrador-personagem compreende seu pai na medida em que a narrativa avança, e compreende seu avô por meio da leitura dos cadernos que deixara e, sobretudo, por meio do confronto entre o que narram os cadernos e o que a história e os relatos da avó mostraram. Isso porque, para seu pai, a vacuidade da figura paterna em grande medida moldou sua própria experiência da paternidade: a obsessão por explicar a Shoah a seu filho deve-se muito ao fato de que, entendendo o trauma pelo qual passara seu pai, poderia compreender o motivo de sua ausência por meio de um isolamento autoimposto e de seu suicídio:

Naquela época eu falava muito pouco com o meu pai. Ele chegava em casa à noite, exausto, e eu já tinha jantado e na maioria das vezes eu estava dormindo. Se eu fosse contar o tempo que passávamos juntos por semana não daria mais que algumas horas, e como nessas horas estavam incluídos os discursos sobre os judeus que morreram nas Olimpíadas de 1973, os judeus que morreram em atentados da OLP, os judeus que continuariam morrendo por causa dos neonazistas na Europa e da aliança soviética com os árabes e da inoperância da ONU e da má vontade da imprensa com Israel, é possível que mais da metade das conversas que ele teve comigo girassem em torno desse tema (LAUB, 2011, cap. "Algumas coisas que sei sobre meu pai”, subcap. 28).

\footnotetext{
${ }^{5} \mathrm{~A}$ versão em e-book do romance não apresenta número de páginas, portanto optamos por indicar a localização aproximada da citação a partir dos capítulos e subcapítulos do romance.
} 
Ocorre, contudo, que o empenho em compreender - e explicar - a Shoah, em vez de ser o elo capaz de vincular o pai a seu pai e ele mesmo a seu filho, o personagem narrador, é o que pouco a pouco os afasta. Isso porque, para o narradorpersonagem, essa espécie de história de segunda mão, que seu pai aprende não porque viveu a experiência, nem porque a ouviu de seu pai, não lhe diz respeito: são apenas histórias que seu pai repete sempre da mesma forma, que em nada diferem do que narrou tantas vezes o cinema, a literatura, o jornalismo. O sentido que emerge dessa relação entre o narrador-personagem e seu pai, tendo como vértice a figura do avô, pode ser aproximada daquela que Deleuze e Guattari (2003, p. 29) identificaram no Kafka de Cartas ao pai: "A questão do pai não se trata de saber como tornar-se livre em relação a ele (questão edipiana), mas como é que se encontra um caminho onde ele não encontrou nenhum. A hipótese de uma inocência, duma aflição comum ao pai e ao filho, é, na verdade, a pior de todas." Pai e filho de Diário da queda compartilham da incompreensão terrificante em relação ao avô que escapou com vida de Auschwitz e reagem de maneiras diferentes a ela; o cerne da questão é que o pai procura, diante do filho, mascarar essa incompreensão recorrendo a narrativas que pudessem explicar o trauma - talvez menos para o seu filho do que para si mesmo - e o que vê o filho é o fracasso dessa tentativa. Apenas a explicitação de tal fracasso é que possibilita que a relação entre pai e filho alcance outro patamar, o que ocorrerá quando um episódio aparentemente sem relação com a questão judia deflagra um conflito entre eles.

A outra ponta, relativa ao tempo do narrador-personagem, enuncia-se de um presente que se constitui de vestígios do passado: os cadernos em que o avô documentou às avessas suas frustrações; as memórias do seu pai, que, acometido pelo Alzheimer, resolve registrar sua vida até o momento em que ela não lhe fizer mais sentido, por causa da doença; e sua própria lembrança a respeito de um episódio da infância que lhe marcou profundamente - a violência brutal, travestida de brincadeira, cometida contra um colega da escola, não judeu. No entanto, e isso é digno de nota, a narrativa efabulada por esse narrador autodiegético não está confinada no passado, como se deveria esperar de um texto assim organizado, uma vez que, descobre-se, ao final, a narração se dirige a um filho que ainda não nasceu, ela aponta para o futuro, para o ainda não.

Assim resumida, a trama poderia dar a falsa impressão de se dispor de maneira mais ou menos simétrica, em degraus temporais que se encaixariam uns nos outros ou em camadas narrativas que se sucederiam temporalmente e, por isso mesmo, constituiriam índices de causalidade discerníveis. Engano. Uma palavra, colhida no interior mesmo do romance, poderia traduzir melhor sua disposição estrutural: espiral. Trata-se de uma elaboração ficcional em que diferentes experiências, vividas direta ou indiretamente em tempos distintos imbricam-se, revelam e velam causas e efeitos sucessivamente, até a última página do romance, que impõe a releitura dos significados das mesmas causas e efeitos, que redimensionam as experiências vividas etc. 
Assim, pode-se considerar que ao leitor é dado a conhecer o narradorpersonagem de maneira paulatina, na medida em que ele conhece seu próprio pai a partir das tentativas desse pai em conhecer - e, sobretudo, compreender - seu avô. Ao mesmo tempo, buscar compreender seu avô é, para o narradorpersonagem, uma forma de compreender seu próprio pai e como ele moldou sua paternidade a partir da presença póstuma (porque acessada por meio dos cadernos apenas depois da sua morte) de seu pai. Isso tudo porque ao narradorpersonagem interessa a constituição de sua própria paternidade que, no presente da narrativa, é ainda apenas um porvir.

Essa espiral em que causas e efeitos não se sucedem, mas, sim, trocam de lugares sucessivamente pode ser observada na organização estrutural da narrativa, dividida em partes intituladas ("Algumas coisas que sei sobre meu avô", "Algumas coisas que sei sobre meu pai", "Algumas coisas que sei sobre mim", "Notas (1)", "Mais algumas coisas que sei sobre meu avô", "Mais algumas coisas que sei sobre o meu pai", "Mais algumas coisas que sei sobre mim", "Notas (2)", "Notas (3)", "A queda" e "O diário"), que, por sua vez, são subdivididas em partes numeradas. À primeira vista, os títulos dos capítulos parecem circunscrever o interesse temático de cada um deles - "Algumas coisas que sei sobre o meu pai" dedicar-se-ia, segundo essa lógica, a narrar questões relativas ao pai do narrador-personagem -, mas isso não ocorre. Um único exemplo será suficiente para comprovar aquilo que antecipamos a respeito do movimento em espiral do romance:

1

Meu avô não gostava de falar do passado. O que não é de estranhar, ao menos em relação ao que interessa: o fato de ele ser judeu (LAUB, 2011, "Algumas coisas que sei sobre meu pai").

3

Eu também não gostaria de falar desse tema. Se há uma coisa que o mundo não precisa é ouvir minhas considerações a respeito (LAUB, 2011, "Algumas coisas que sei sobre o meu pai”).

4

Nos meses antes de completar treze anos eu estudei par fazer Bar Mitzvah. Duas vezes por semana eu ia à casa de um rabino (LaUb, 2011, "Algumas coisas que sei sobre o meu pai).

Os fragmentos transcritos são as frases iniciais dos subcapítulos 1, 3 e 4 do capítulo intitulado "Algumas coisas que sei sobre o meu pai". Neles, flagram-se as estratégias narrativas e estruturais que fundamentam todo o romance. A primeira delas, relacionada ao que vínhamos discutindo, diz respeito ao deslizamento constante entre as experiências de vida dos três personagens principais, narradorpersonagem, pai e avô. Nesse primeiro capítulo, dedicado ao avô, nota-se, logo no 
início, que interessa também ao narrador-personagem falar de si. Tanto um como outro, por motivos diferentes, recusam-se a falar da Shoah; tanto um como outro, de formas diferentes, não deixam de falar dela: o avô escrevendo um diário que é o testemunho de sua incapacidade, depois de tudo o que viveu, de levar uma vida normal e o narrador-personagem descobrindo, paulatinamente, que suas marcas traumáticas são transgeracionais e que sua recusa em as enfrentar já é um sintoma disso. Advém desse deslizamento um outro, que diz respeito à maneira como episódios de vida aparentemente sem relação entre si, narrados sem que se procure estabelecer, diretamente, uma relação causal entre eles, vão, ao longo do romance se retecendo, oferecendo ao leitor não um quadro objetivo de acontecimentos que se interligam diretamente, mas uma trama complexa em que, por exemplo, a recusa de falar sobre suas experiências no campo de concentração, no caso do avô, relaciona-se com o fato de o narrador-personagem frequentar uma escola para judeus em que um único aluno (o que é vítima de atos de grande violência por parte dos demais) é não judeu.

Outra marca estrutural que poderá ser observada em todo o romance diz respeito à emergência da memória a partir mesmo de sua recusa, ou seja, o avô, ao não falar do trauma que viveu, gera o estopim para que seu filho, pai do narradorpersonagem, esforce-se em entender e fazer com que seu filho entenda, por outros meios que não o relato direto, a violência de que foi vítima seu pai e como ela foi a responsável por lhe sequestrar a presença. E assim, o pai do personagem narrador mobiliza uma outra memória a respeito da Shoah para explicá-la ao seu filho:

Meu pai é um leitor bastante razoável. Apesar disso, não lembro de ele ter citado mais do que dez livros durante a minha adolescência. Talvez não mais que cinco. Lembro de um apenas, É isto um homem?, que ele leu numa edição importada, porque ele vivia repetindo as descrições sobre o funcionamento de um campo de concentração, as noites em que Primo Levi dormia dividindo a cama com um relojoeiro, as histórias sobre números altos e baixos, tarefas, uniformes, sopa (LAUB, 2011, cap. "Algumas coisas que sei sobre mim", subcap. 3).

Diante disso, o narrador-personagem, impelido a saber sobre a Shoah desde muito jovem, só consegue compreender seu alcance em sua vida quando lê os diários do avô e compreende a "espiral de ódio" (LaUB, 2011, cap. "Algumas coisas que sei sobre o meu avô", subcap. 9) que, de uma forma ou de outra, tragou sua família e da qual ele pretende se livrar para poder fundar uma outra e diferente relação com seu filho que está sendo gestado.

A história, reorganizada a partir de uma hipotética ordem temporal, noticiaria um fio narrativo que iria do passado do avô em Auschwitz, sua libertação, sua vinda ao Brasil, a constituição de uma família, a escrita dos cadernos e seu suicídio; depois, a tentativa do pai em compreender a ausência paterna, mesmo quando vivo, a infância do narrador-personagem entre outras crianças judias, o episódio 
da queda do colega não judeu, a briga com o pai, a mudança de escola e a recusa ao pertencimento ao judaísmo, o início do alcoolismo, seus casamentos fracassados, a descoberta da doença do pai e, finalmente, a descoberta da própria paternidade. Como se sublinhou, no entanto, a ordem a partir da qual a instância narrativa decide comunicar tais eventos não segue a cronologia dos acontecimentos e não parece estar vinculada a uma causalidade explícita.

Assim, se a espiral que estrutura a narrativa de Diário da queda é constituída por esses fragmentos de vida retirados de diferentes momentos que se intercambiam na medida em que se constituem como experiências diretas ou indiretas, o eixo a partir do qual se move a espiral é, no entanto, o futuro - ou, pelo menos, é disso que o narrador-personagem tenta se convencer. À primeira vista, parece ser a aposta em um vir a ser que abre ao narrador-personagem a possibilidade e a motivação de olhar para o passado e enfrentar as memórias que, sendo ou não resultado de sua experiência direta, modelaram seu presente:

[...] mas você olha para mim e sabe intuitivamente o que está por trás de cada uma delas, o que significa a pessoa na sua frente, meu avô diante do meu pai, meu pai diante de mim, eu agora e a sensação que acompanhará você enquanto os anos passam e também começo a esquecer todo o resto, o que a esta altura não é mais alegre nem triste, bom ou ruim, verdade ou mentira no passado que também não é nada diante daquilo que sou e serei, quarenta anos, tudo ainda pela frente, a partir do dia em que você nascer (LAUB, 2011, cap. "O diário", subcap. 40).

Depreende-se, das principais linhas temáticas e opções estruturais, que, no romance de Laub, a memória do narrador-personagem e a sua própria constituição identitária compõem-se de rastros das suas próprias memórias das suas experiências de vida - aqui, a violência cometida contra o garoto não judeu e todas as consequências advindas desse episódio são fundamentais -, por rastros das memórias de outros (de seu pai, de seu avô, de Primo Levi) e, sobretudo, pela articulação disso a partir do seu presente e com vistas a um futuro, em um percurso que, à primeira vista, cumpre o cronotopo temporal típico da modernidade: a rememoração do passado, o presente como espaço da transição e ao futuro reservada a redenção (no caso do romance, a possibilidade de apagar o passado para apostar em uma vida nova, livre dos traumas).

Outro aspecto é digno de nota, ainda. Se as memórias alheias se inserem no jogo narrativo do narrador-personagem como rastros que lhe permitem construir sua identidade na convergência entre o subjetivo e o histórico - em um processo que, como vimos, relaciona-se com o testemunho -, o discurso daí resultante, como não poderia deixar de ser em um momento em que as certezas históricas e as possibilidades de significação subjetivas estão rasuradas, também não ultrapassa o limite do rastro. Ou seja, da espiral de memória subjetiva e histórica resultam uma existência e uma experiência que também precisam ser investigadas e decifradas 
para além de uma realidade individual. Isso porque a rememoração do trauma da Shoah não é apenas um exercício de memória individual, mas tem implicações éticas, ideológicas, coletivas.

Isso não significa dizer que o impulso, aqui, é semelhante àqueles "trabalhos de memória" do século XX, modernistas. No caso de autores como Graciliano Ramos, Pedro Nava e Ferreira Gullar, Chiara (2015, p. 162) afirma que é possível notar em suas obras de extração memorialista: Infância, Memórias do cárcere, Baú de ossos e Poema sujo: "uma inclinação para a participação social e/ou política com tendências libertárias (mais obviamente partidárias em Graciliano e Gullar) e a noção de que dão testemunho de alcance maior do que meras confissões de intimidade". Percepção parecida é a de Miranda (1992, p. 125), que observa como, em Graciliano Ramos de Infância e Memórias do cárcere, a rememoração de "um incidente estritamente pessoal [...] é desveladora de uma situação repressiva-opressiva que ultrapassa o âmbito do particular e o contextualiza numa rede de significações mais abrangente". O que ocorre em Diário da queda talvez possa ser compreendido, mesmo que esquematicamente, como o inverso desse impulso modernista de inscrever na subjetividade o histórico a fim de fazer com que este se sobreleve em relação àquela, em um posicionamento de confiança na evolução histórica característico da alta modernidade. Em Diário da queda, o que acontece é a emergência de uma concepção de temporalidade moderna - e, portanto, histórica - rasurada, como demonstraremos na última seção deste ensaio.

Traço recorrentemente sublinhado pelos críticos de parte da literatura contemporânea é a sua alegada incapacidade de ultrapassar os limites da individualidade em direção à alteridade e, menos ainda, ao coletivo. Embora nem sempre essa crítica seja justificada, não se pode negar que, em um romance como o de Laub, o movimento é o de explicitar que a história só faz sentido, na contemporaneidade, quando inscrita na individualidade mais imediata. É por isso que o que garante o vínculo entre o narrador-personagem, seu pai e seu avô não são os relatos da Shoah que seu pai insiste em repetir nas horas de convívio entre eles e sim o momento preciso em que esses relatos começam a fazer sentido para si próprio: "Para mim tudo começa aos treze anos, quando deixei João cair na festa de aniversário" (LAUB, 2011, cap. "Algumas coisas que sei sobre o meu pai", subcap. 22). A citação remete a um contexto em que o narrador-personagem explica a maneira pela qual seu pai começou a se interessar pelas questões do judaísmo e da Shoah, momento em que esse pai começa a ler os cadernos deixados pelo seu próprio pai. Digno de nota é o fato de que, para o narrador-personagem, o momento em que o fato de ser judeu começa a fazer sentido é quando ele é acometido pelo remorso de ter participado do grupo de garotos judeus que deixaram que o único não judeu da escola caísse depois de uma brincadeira tradicional em que garotos são jogados para cima durante o Bar Mitzvah. Ou seja, o ser judeu ganha sentido quando, paradoxalmente, perde o sentido, quando o narrador-personagem opta pelo não pertencimento, o que se desdobrará em uma relação conflitiva com o pai, porta-voz exigente desse pertencimento que ele passa a recusar: 
Porque eu não tinha nada em comum com aquelas pessoas além do fato de ter nascido judeu, e nada sabia daquelas pessoas além do fato de elas serem judias, e por mais que tanta gente tivesse morrido em campos de concentração não fazia sentido que eu precisasse lembrar disso todos os dias (LAUB, 2011, cap. "Algumas coisas que sei sobre meu pai”, subcap. 30).

\section{Uma temporalidade rasurada}

Em sua obra Depois de 1945: latência como origem do presente, Hans Hulrich Gumbrecht (2014) realiza um esforço teórico-analítico, analisa aspectos da história do pós-guerra a partir de eventos históricos, reflexões filosóficas, artefatos culturais e a partir de sua própria experiência pessoal e profissional. Não se trata, evidentemente, da proposição de um caminho metodológico de análise literária, mas alguns aspectos das reflexões de Gumbrecht (2014) nesse livro podem iluminar a leitura do romance de Michel Laub.

O mais contundente desses aspectos é aquele que discute a questão da temporalidade contemporânea, ou melhor, da experiência do sujeito contemporâneo em relação ao tempo. Aproximando-se - sem nem sempre se alinhar - às reflexões a respeito do tempo levadas a cabo pelos filósofos que, a partir da década de 1980, foram designados como pós-modernos (Lyotard e Derrida, principalmente), Gumbrecht propõe uma noção de temporalidade que questiona aquela que sustentou a alta modernidade, uma temporalidade compreendida como um percurso linear, que se direciona do passado ao futuro e que identifica tal futuro como o local do progresso, da emancipação, da utopia. Para o autor, o que ele designa por latência, conceito que ele aborda em diferentes momentos de sua carreira, em diferentes obras, está relacionado com uma rasura na concepção de linearidade temporal. Embora não chegue a preconizar a falência do "cronótopo historicizante" da modernidade, Gumbrecht percebe que o pós-guerra trouxe modificações - ele chama de "rugas" - na concepção temporal do Ocidente:

Como a geração anterior considerava estas condições [deixar o passado para trás, passar por um tempo de simples transição e entrar no futuro enquanto horizonte de possibilidades meta-históricas], transculturais e, por isso mesmo, inevitáveis, não havia como pensar que alguma coisa sobre o "tempo" começara a mudar quando as ações diárias de nossos pais - e mais tarde as nossas - deixaram de convergir com o cronótopo historicista e com seus efeitos familiares. Ser incapaz de deixar o passado ou nossos pais para trás [...] deverá ser o resultado do silêncio e da repressão, de deixar por dizer certos fatos e ações - uma forma de (in)ação que ganha uma enorme dimensão de latência, a saber, a presença do passado que foi e que é, ao mesmo tempo, perturbador e inacessível (GuMBRECHT, 2014, p. 320). 
A longa citação coloca em pauta, como se vê, a crise de uma concepção temporal, que, embora não tenha desaparecido, encontra-se rasurada, segundo o autor, desde, pelo menos, a década de 1950. O que nos interessa, no âmbito desta discussão, é observar como os conceitos-chave de memória, escrita e rastro, que nos deram elementos para a reflexão sobre o romance Diário da queda, articulam-se à essa temporalidade rasurada.

Como discutimos, o romance de Laub mobiliza estratégias narrativas para colocar em pauta/construir a memória - em todos os aspectos evanescentes, fluidos, imprecisos. A voz de um narrador autodiegético, que se coloca em causa, ao mesmo tempo que coloca em causa seu próprio ato narrativo - em outras palavras, um narrador que narra eventos (e memórias de eventos) e que, ao narrar, constrói os eventos que narra - faz sobrepor, no romance, duas esferas de significados que se relacionam com essa rasura na concepção de temporalidade moderna.

O narrador-personagem do romance de Laub narra as memórias, suas e alheias, em uma espiral cujo eixo se ancora no futuro: seu esforço é o de, enunciando o passado e revelando o que ficou por dizer, resultado do silêncio e da repressão, como afirma Gumbrecht (2014), seja capaz de atravessar rapidamente o presente para, enfim, poder viver o futuro "a partir do dia em que você [ele se refere ao filho que está sendo gestado] nascer”. A aposta no futuro baseia-se, para o narradorpersonagem, em uma espécie de expurgo do passado, que se daria por meio do processo de revolvê-lo, interpretá-lo, comunicá-lo e, enfim, abandoná-lo; algo que ele faz no presente da narração enquanto escreve a carta (que é o documento que lemos) a seu filho que está para nascer. Não sabemos o que aconteceria depois, caso o romance de Laub não se encerrasse nesse ponto: o narrador-personagem colocou um ponto final em suas memórias, então fechará seu caderno, o encerrará em uma gaveta e ali jazerão seus medos e traumas? Provavelmente não. Ou então, por que instauraria um interlocutor nesses escritos? O que é certo, no entanto, é que o narrador-personagem conclui seu trabalho de memórias para viver, diferentemente de seu pai e de seu avô, que tinham, em seus horizontes, a morte.

Se o narrador-personagem instaura um interlocutor nessa escrita, se ela se dirige a alguém - no caso, o seu filho que sequer nasceu - é porque nessa escrita, nessas memórias, esse filho já está implicado. Talvez aqui possamos identificar a rasura que mencionamos: a escrita se aproxima do rastro, na medida em que fará perpetuar a memória para esse filho que ele julga, erroneamente, que estará livre dela. O filho não pode começar do zero "sem a necessidade de carregar o peso disso e de nada além do que descobrirá sozinho", uma vez que o gesto de narrar (e, no caso, de escrever) não se esgota no contar uma reminiscência, uma lembrança, mas está relacionado com a instauração, no presente, de significados que podem ter sidos gerados no passado, mas que nele não ficaram retidos, nem imobilizados.

Esses dois movimentos - o de tentar o expurgo do passado, ao mesmo tempo em que, às vezes inadvertidamente e à revelia da vontade, o de garantir-lhe uma sobrevida - é o que Gumbrecht (2015, p. 11) chama de latência: "uma presença, 
entendida como uma espécie de 'passageiro clandestino', que pode produzir efeitos e irradiar energia, ao mesmo tempo que escapa à possibilidade de ser identificada e apreendida".

O romance de Michel Laub narra o esforço do narrador-personagem em se ver livre do passado - o seu, o de seu pai e o de seu avô. Um esforço que se percebe pelo esquadrinhamento de suas memórias e das memórias alheias que o constituem enquanto sujeito, embora ele acredite, empenhado na tarefa hercúlea de enfrentar os rastros para apagá-los, que ele poderia delas prescindir para viver o "tudo ainda pela frente". Paradoxalmente, o gesto de superação dos rastros das memórias se faz por meio da escrita, e o narrador-personagem, ao imprimir as letras na página, mais uma vez imprime o passado no presente - e no futuro, levandose em consideração que instaura um leitor para seu texto: seu filho que está sendo gestado. Os aspectos formais do romance, seus vertiginosos movimentos de uma espiral balançando ao vento - que proporciona aquela peculiar ilusão de ótica que torna imprecisa, para o observador, a direção em que ela se move -, os eventos do passado remoto narrados para conferir sentido ao presente, e vice-versa, apontam para essa impossibilidade de colocar o passado no seu lugar, de impedi-lo de invadir o presente, embora o esforço seja o de fazê-lo.

\section{Referências}

BRENDLeR, Guilherme. Michel Laub se rende ao judaísmo pela primeira vez. Entrevista com Michel Laub. Folha de S. Paulo, São Paulo, 19 mar. 2011. On-line. Disponível em: <https://goo.gl/jUkG1N>. Acesso em: 15 nov. 2017.

Chinar, Ana Cristina. Corpos em conflito e memórias extremas em Graciliano Ramos, Pedro Nava e Ferreira Gullar. In: Fukelman, Clarisse (Org.). Eu assino embaixo: biografia, memória e cultura. Rio de Janeiro: Editora da UERJ, 2014.

Deleuze, Gilles; Guattari, Félix. Kafka: para uma literatura menor. Tradução de Rafael Godinho. Lisboa: Assírio e Alvim, 2003.

Gagnebin, Jeanne Marie. Lembrar, escrever, esquecer. São Paulo: Ed. 34, 2006.

Genette, Gérard. Discurso da narrativa. 3. ed. Tradução de Fernando Cabral Martins. Lisboa: Vega, 1995.

Gumbrecht, Hans Ulrich. Depois de 1945: latência como origem do presente. Tradução de Ana Isabel Soares. São Paulo: Editora da Unesp, 2014.

Gumbrecht, Hans Ulrich. Nosso amplo presente. Tradução de Ana Isabel Soares. São Paulo: Editora da Unesp, 2015.

HidAlgo, Luciana. Autoficção brasileira: influências francesas, indefinições teóricas. Alea, Rio de Janeiro, v. 15, n. 1, p. 218-231, jan./jun. 2013. 
KLINGER, Diana. Escrita de si como performance. Revista Brasileira de Literatura Comparada, n. 12, p. 11-30, 2008.

KLINGER, Diana. Escritas de si, escritas do outro: o retorno do autor e a virada etnográfica. 2. ed. Rio de Janeiro: 7 Letras, 2012.

LAfetá, João Luiz. O mundo à revelia. In: Prado, Antonio Arnoni (Org.). A dimensão da noite. Rio de Janeiro: Duas Cidades; São Paulo: Ed. 34. p. 72-102.

LAUB, Michel. Diário da queda. São Paulo: Companhia das Letras, 2011. (E-book).

Paraná. Secretaria de Cultura. Biblioteca Pública do Paraná. Michel Laub encerra carreira de romancista após trilogia. Curitiba, 7 nov. 2013. On-line. Disponível em: $<$ https://goo.gl/Yn5rır>. Acesso em: 15 nov. 2017.

Pereira, Rogério. Merecido descanso. Entrevista com Michel Laub. Rascunho, Curitiba, n. 133, maio 2011. Disponível em: <http://rascunho.com.br/ merecido-descanso/>. Acesso em: 15 nov. 2017.

Miranda, Wander Melo. Corpos escritos. São Paulo: Editora da USP; Belo Horizonte: Editora da UFMG, 1992.

SARLo, Beatriz. Tiempo pasado: cultura de la memoria y giro subjetivo. Una discusión. Buenos Aires: Siglo Veintiuno, 2005.

Recebido em 25 de julho de 2017.

Aprovado em 25 de setembro de 2017.

\section{Resumo/Abstract/Resumen}

\section{Trauma, memória e latência em Diário da queda, de Michel Laub}

\section{Rejane Cristina Rocha}

O romance Diário da queda, de Michel Laub, coloca em pauta a memória da Shoah, narrando as ressonâncias do trauma em três gerações de uma mesma família. Os procedimentos narrativos mobilizados para a construção das memórias - narrador em primeira pessoa que narra as suas próprias memórias, cravejadas pelas memórias de outrem; movimento espiralar que embaralha passado, presente e porvir, sem definição clara das origens das diferentes dores tematizadas pelo enredo - permitem que se entreveja a maneira como as marcas do passado, estendidas ao presente por meio da escrita, são inescapáveis, embora, paradoxalmente, a própria escrita seja usada com o objetivo de expurgar o passado.

Palavras-chave: narrativa brasileira contemporânea, memória, Michel Laub. 
Trauma, Memory and Latency in Diário da queda, by Michel Laub

\section{Rejane Cristina Rocha}

The novel Diário da queda, by Michel Laub, recounts the memoirs of Shoah, who narrates the repercussions of tragedy on three generations of the same family. The narrative techniques employed to construct the stories - first-person narration telling his own story, interspersed with the recollections of others in a spiraling blend of the past, present and future without clearly defining the origins of the suffering resulting from past traumas - give an insight into how the effects of the past, extended into the present through writing, are inescapable even though, paradoxically, the act of writing is itself used in an attempt to purge the past.

Keywords: contemporary Brazilian novel, memory, Michel Laub.

\section{Trauma, memoria y latencia en Diário da queda, de Michel Laub}

\section{Rejane Cristina Rocha}

La novela Diário da queda, de Michel Laub, pone en escena la memoria de la Shoa, narrando las resonancias del trauma en tres generaciones de una misma familia. Los procedimientos narrativos empleados para la construcción de las memorias - narrador en primera persona que narra sus propias memorias, engalanadas por las memorias de otros; movimiento en espiral que baraja pasado, presente y porvenir, sin definir claramente los orígenes de los diferentes dolores tematizados por la trama - permiten que se entrevea la manera en que las huellas del pasado, extendidas al presente mediante la escritura, son inescapables, aunque, paradójicamente, la propia escritura sea usada con el objetivo de expurgar el pasado.

Palabras clave: narrativa brasileña contemporánea, memoria, Michel Laub. 